\title{
Investigation of availability, demand, targets, and development of renewable energy in 2017-2050: a case study in Indonesia
}

\author{
Erdiwansyah Erdiwansyah $^{1,6}\left(\mathbb{D} \cdot\right.$ Mahidin Mahidin $^{2} \cdot$ Husni Husin $^{2} \cdot$ \\ Nasaruddin Nasaruddin ${ }^{3} \cdot$ Khairil Khairil $^{4} \cdot$ Muhammad Zaki $^{2} \cdot$ Jalaluddin Jalaluddin $^{5}$
}

Received: 11 May 2020/Revised: 10 September 2020/ Accepted: 3 December 2020/Published online: 16 January 2021

(C) The Author(s) 2021

\begin{abstract}
Abundant potential of renewable energy (RE) in Indonesia is predicted to replace conventional energy which continues to experience depletion year by year. However, until now, the use of RE has only reached $2 \%$ of the existing potential of $441.7 \mathrm{GW}$. The main overview of this work is to investigate the availability of RE that can be utilized for electricity generation in Indonesia. National energy demand and targets in the long run during the 2017-2050 period are also discussed. Besides, government policies in supporting RE development are considered in this work. The results show that the potential of RE in Indonesia can be utilized and might replace conventional energy for decades. The use of RE for electricity generation can be achieved by employing a government policy that supports the investor as the executor of RE development. The selling price of electricity generated from RE is cheaper than electricity generated from fossils; this makes economy is more affordable for people. Finally, the target set by the government for utilizing RE as the main energy in Indonesia can be done by implementing several policies for the RE development. Thus, greenhouse gas emissions and the use of petroleum fuels can be reduced.
\end{abstract}

Keywords Energy potential · Energy demand · Energy development · Economic growth · Energy policy · Energy targets

\section{List of symbols}

RE Renewable energy

SD Sustainable development

MTOE Million tonnes of oil equivalent

BBM Bahan Bakar Minyak

Erdiwansyah Erdiwansyah

erdi.wansyah@yahoo.co.id

$\triangle$ Mahidin Mahidin

mahidin@unsyiah.ac.id

1 Doctoral Program, School of Engineering, Universitas Syiah Kuala, Banda Aceh 23111, Indonesia

2 Department of Chemical Engineering, Universitas Syiah Kuala, Banda Aceh 23111, Indonesia

3 Department of Electrical and Computer Engineering, Syiah Kuala University, Banda Aceh 23111, Indonesia

4 Department of Mechanical Engineering, Universitas Syiah Kuala, Banda Aceh 23111, Indonesia

5 Department of Accounting, Universitas Syiah Kuala, Banda Aceh 23111, Indonesia

6 Faculty of Engineering, Universitas Serambi Mekkah, Banda Aceh 23245, Indonesia
PLN Perusahaan Listrik Negara

LPG Liquefied petroleum gas

CSA Central Statistics Agency

MMSCF Million standard cubic feet per day

PLTP Pembangkit Listrik Tenaga Panas

PLTMH Pembangkit Listrik Tenaga Mikrohidro (micro hydro power plant)

PLTG Pembangkit Listrik Tenaga gas (gas power plant)

PLTS Pembangkit Listrik Tenaga Surya (solar power generation)

PLTB Pembangkit Listrik Tenaga Biomassa (biomass power plant)

TSCF Trillion standard cubic feet

GWp Gigawatt-peak

PLTW Pembangkit Listrik Tenaga Wave (tidal/wave power plant)

KEN Komite economic national

EM Energy mix

LC Low carbon

GWh Giga what per hour

ESBP Electricity supply business plan

KEN Komite economic national 


$\begin{array}{ll}\text { DME } & \begin{array}{l}\text { Dimethyl ether } \\ \text { LNG }\end{array} \\ \text { PLTA } & \begin{array}{l}\text { Pembangkit Listrik Tenaga air (hydroelectric } \\ \text { power plant) }\end{array} \\ \text { PLTD } & \begin{array}{l}\text { Pembangkit Listrik Tenaga diesel (diesel power } \\ \text { plant) } \\ \text { Pembangkit Listrik Tenaga gas dan uap (gas } \\ \text { and steam power plants) }\end{array} \\ \text { PLTGU } & \begin{array}{l}\text { Pembangkit Listrik Tenaga Mesin gas (gas } \\ \text { engine power plant) }\end{array} \\ \text { PLTMG } & \text { Gigawatt } \\ \text { GW } & \text { Megawatt } \\ \text { MW } & \text { Ungawatt-peak } \\ \text { UNEP } & \text { United Nations Environment Program }\end{array}$

\section{Introduction}

Indonesia is one of the Southeast Asia countries and even in the world that has problems with the energy crisis. The number of Indonesia's oil imports during the 2009-2019 period reached 49.1 million tons, with an average import of 3.6\%/year (BPS 2019a). Based on the energy mix (EM), sustainable development (SD) and low carbon (LC) scenario show that Indonesia's energy demand in 2025 will be 170.8, 154.7 and 150.1 MTOE, respectively. Meanwhile, in 2050, Indonesia's overall energy demand will reach 548.8, 481.1 and 424.2 MTOE (ESDM 2019). Total primary energy production consisting of petroleum, natural gas, coal, and other REs in 2018 reached 411.6 MTOE. From the total production, $64 \%$ or 261.4 MTOE were exported mainly for coal and LNG. Final energy consumption in 2018 (without biomass) reached 114 MTOE consisting of transportation sector of $40 \%$, industry of $36 \%$, household of $16 \%$, commercial of $6 \%$, and other sectors of $2 \%$.

Energy is one of the main factors in the context of sustainable development to eradicate poverty, protect the environment, increase prosperity, and speed development (Santika et al. 2020). The abundant availability of RE in Indonesia has been widely expressed by several researchers and has been widely discussed earlier. Indonesia has the highest availability of coal energy at $51 \%$ in Southeast Asia (Erdiwansyah et al. 2019a). Meanwhile, Indonesia's oil production level is the second highest after Brunei Darussalam. Indonesia's oil production is $12.02 \%$ while Brunei Darussalam's natural gas production is $18.06 \%$ (Erdiwansyah et al. 2019). Indonesia has targeted the use of RE in 2025 is $23 \%$ with a feed-in tariff policy system. RE is very possible to be used as the main energy to replace petroleum (fossil) which continues to experience depletion every year. Discussions on Indonesia's RE policy and prospects have been conveyed (Maulidia et al. 2019). The application of $\mathrm{RE}$ in various ways can also reduce carbon emissions which has been providing high enough air pollution, especially from vehicles and industry (Deendarlianto et al. 2020). Determination of the RE target of $23 \%$ is in line with the determination of the use of oil consumption by $25 \%$ nationally. The selection of a sustainable solar system (solar), a sustainable biogas system (biogas), an efficient lighting device (Lighting), an efficient cooling device (Cooling), and an efficient cooking stove (Cooking) scenario aims to reduce emissions levels sustainably. In this case, this action is estimated to be able to save cooling energy by $22.99 \%$ in 2050 (Kusumadewi and Limmeechokchai 2017; Erdiwansyah et al. 2019b; O'Ryan et al. 2020; Ben Jebli et al. 2020; Khanna et al. 2019). One of the RE developments that has attracted foreign investors in solar PV is reported by (Kennedy 2018). The installed solar PV capacity increased from 9 megawatts (MW) to more than $240 \mathrm{MW}$ in 2017. However, foreign investors often face problem such as lack of government policy towards RE developers. Therefore, many interventions are not expected in the field. Targets for achieving efficient use of RE systems have been prioritized in the decarbonization of Indonesia's electricity systems (Indra Al Irsyad et al. 2020).

The application of RE has also greatly impacted the economic improvement and reduced carbon dioxide emissions. In addition, adverse effects on climate change and global warming can be reduced by applying RE permanently (Gozgor et al. 2020). Investigations on the effects of economic policy uncertainty differentiation on various types of energy company investments using the panel regression model have been reported (Liu et al. 2020). Economic growth with RE consumption can drive for longterm financial development (Eren et al. 2019). Investigations into the short-term and long-term economic growths of RE use have also been discussed recently (Alam and Murad 2020), in which the results show that the use of RE can significantly increase economic growth and improve welfare. The global energy transition system is one of the trends to provide promising economic opportunities in the future (Jenniches 2018). The use of RE can save money commonly used for energy needs. This is because RE is cheaper than fossil fuels. The impact of RE and financial development on carbon dioxide $\left(\mathrm{CO}_{2}\right)$ emissions and the economy has been reported (Charfeddine and Kahia 2019), in which the results show that RE consumption and financial development influence $\mathrm{CO}_{2}$ emissions and economic growth. The effect of economic growth on the consumption of renewable and non-RE used to inspect Asia-Pacific Economic Cooperation (APEC) countries (Zafar et al. 2019). The consumption of renewable and non-RE used to achieve the target in reducing emissions 


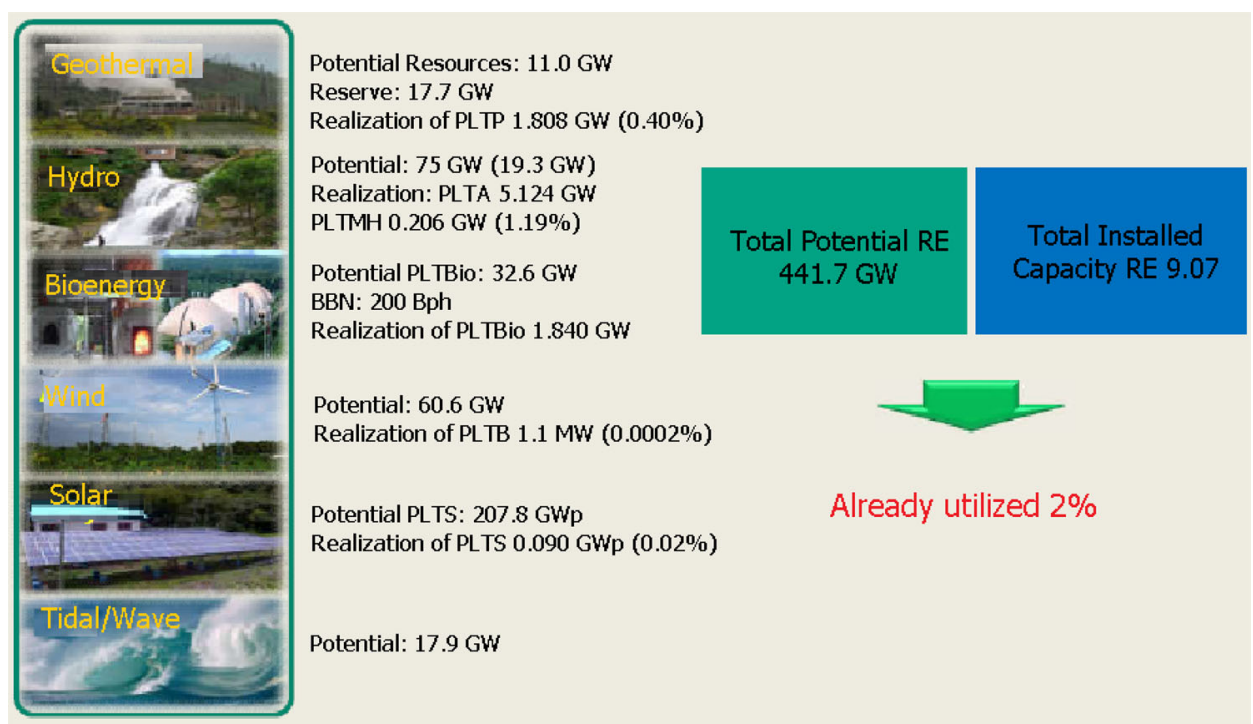

Fig. 1 RE potential in Indonesia

globally has been implemented since 1997-2014 (Alola et al. 2019). While in Indonesia, emissions reductions have also been carried out such as the development of RE by implementing several policies for developers. Policies that support RE developers must be made and implemented by the stakeholders. Besides, the government must also target more efficient use of energy in the future. The government's step in targeting the use of RE in the future is very appropriate. Besides, the government can save more budgets and can further improve the welfare of the community.

The energy found in Indonesia is very abundant, especially those from renewable energy (RE) sources though they have not been used optimally. This is because the available resources are inadequate to support the development of RE. The study became important due to its discussion on the availability, demand, targets, economic growth, and development of RE might improve the quality of government planning in energy, especially for RE development planning. Issues in this article can enhance the future government planning for about 30 years (up to 2050).

\section{Material and method}

The process of analysis is a very important thing to do in a study. There are two rare methods used in the study, namely analysis and categorization. The analysis process is based on the arguments contained in the categorized literature. The arguments reviewed in the study are explained in detail in Sect. 3, while the fifth section presents overall conclusion. The literature analyzed in this review was obtained from various databases including Science Direct,
Web of Science, IEEE, and various research results both from government institutions and from universities. The database generally produces various fields of science such as the development of RE that has high quality.

\subsection{Analysis data}

The literature review analyzed in this research is based on RE sources that cannot be utilized optimally as shown in Fig. 1. Where the total potential of RE found in Indonesia reaches $441.7 \mathrm{GW}$ with an installed capacity of $9.07 \mathrm{GW}$. Meanwhile, the new energy can be utilized to date has only reached $2 \%$. The analysis and review in this paper discuss the availability, demand, targets, economic growth, and development of $\mathrm{RE}$ in Indonesia in the period of 2017-2050. Renewable energy discussed includes geothermal, hydropower, bioenergy, wind power, solar power, and tidal/wave. Once the analysis of RE availability is done, energy targets and demand in the next few years are then discussed. Then, energy supply, economic growth, $\mathrm{RE}$ policies, risks, and RE challenges are described sequentially and finally concluded.

\subsection{Categorization}

There are 3 types of references used in the study, namely literature taken from academics, reports from industry, and documents about various policies. The last two types of references were collected online by the author or through research submitted. Collection of academic literature was obtained from databases such as Science Direct, Web of Science, and IEEE using the keywords of potential RE. In this stage, identification was carried out aiming to produce 
information contained in the literature according to their respective year of publication. The methodology used should be more inspirational and make sense to the reader. All reference sources reviewed in this paper focus on RE. The process of searching literature was carried out based on criteria and selected whether they met the research objectives. Study selection as a reference was obtained from journals such as RE, Target Energy, Energy Policy, Economic Growth, Renewable and Sustainable Energy, Energy Demand, and Energy Supply. The search for journal sources needed contains keywords related to energy. This paper summarizes seven categories, namely: energy potential (EP), RE target (TRE), energy demand (ED), energy supply (ES), economic growth (EG), policy $\mathrm{RE}$ (PRE), risks and challenges of RE (RCRE). These topics are independent and are not yet connected to other researches.

\section{Discussion}

The installed power plant capacity in Indonesia until 2018 was 56,509.53 MW. This capacity was supplied by PLN of $40,486.60 \mathrm{MW}$ by private sector of $13,350.79 \mathrm{MW}$, and by rental power plants of 2,672.14 MW. Most of the sources of electricity generation in Indonesia are coal energy of 49\%, PLTG/PLTGU/PLTMG of 27\% from PLTD of $12 \%$, PLTA/PLTM of $11 \%$, PLTP of $3 \%$, and the rest comes from RE. The capacity of this power plant continues to increase every year from 48,739 MW in 2014 (Rahardjo and Fitriana 2005; Alhamri and Suryani 2016).

Petroleum production in Indonesia in 2018 decreased to 283 million/barrels (778 thousand b/d) compared to 2009 of 346 million/barrels (949 thousand b/d) (Purwanto et al. 2016; ESDM 2019; Nugroho 2019). The decline in oil production was caused by several factors such as production wells that were no longer feasible. While the development of new wells for production was still very limited. However, until now, Indonesia has a dependency on petroleum. The available petroleum cannot meet the needs of the existing refineries, so the government of Indonesian continues to import from other countries such as the

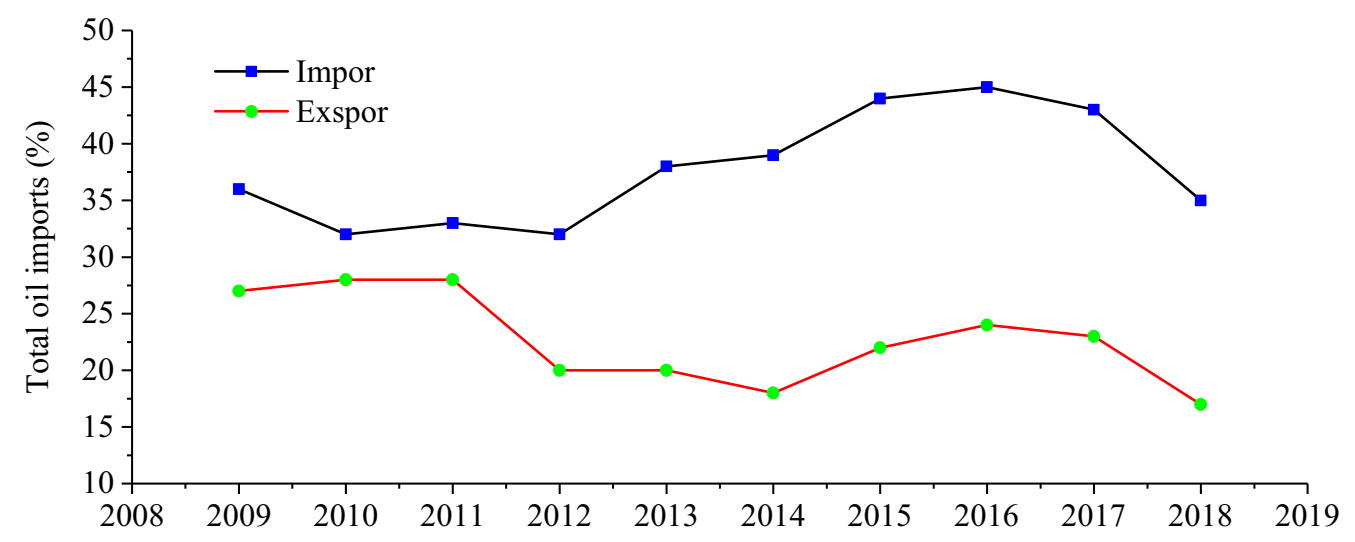

(a) Total oil imports from 2009-2018

(b) Total production and oil impor in 2009-2018

Fig. 2 a, b Total imports, exports and Indonesian oil production for 2009-2018 


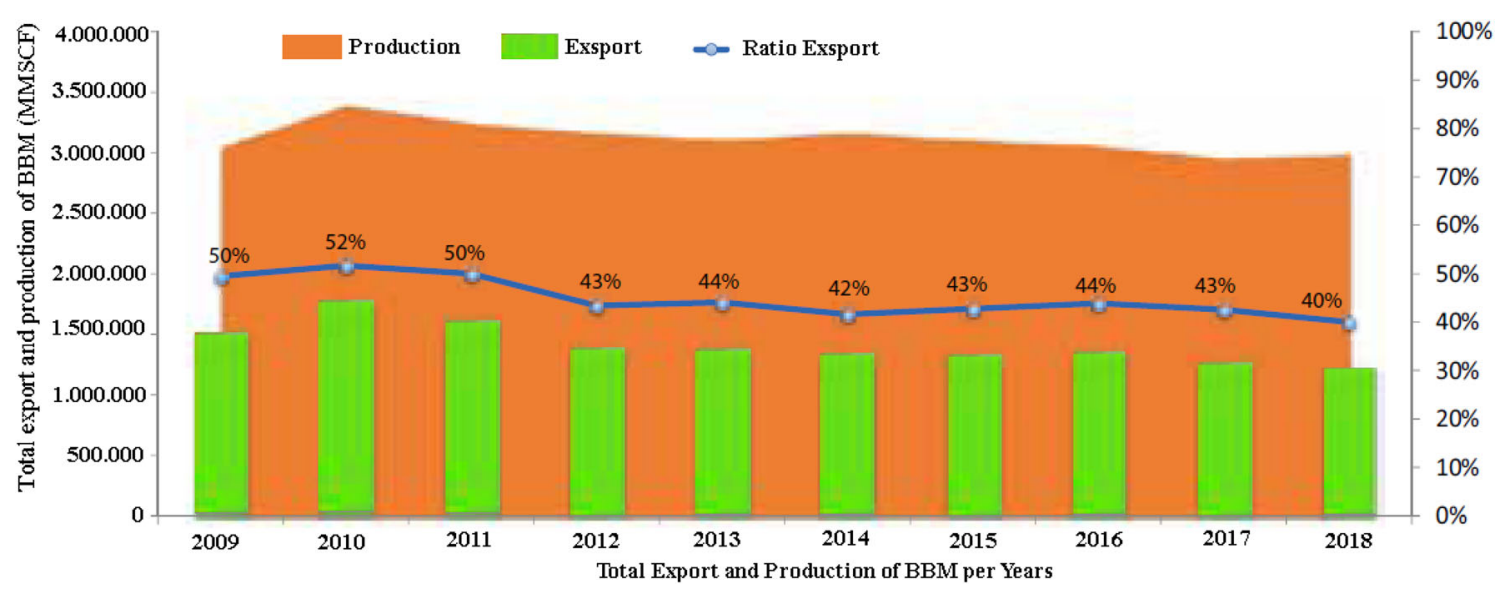

Fig. 3 Total export and production of natural gas

Middle East. The number of Indonesia's oil imports from 2009 to 2018 reached more than 35\% as shown in Fig.2a.

In general, energy demand in 2018 reached 465.07 million barrels/year including biodiesel fuel. Total domestic oil production is 278.01 barrels, while the total amount of oil imported by the government of Indonesian from oil-producing countries is 165.04 barrels/year. The comparison of total oil production and import each year can be seen in Fig. 2b. In 2017, Indonesia was ranked the third-largest country in terms of crude oil imports after Singapore and Thailand at US\$21.04 and US\$20.1 billion, respectively. The total of Indonesia's oil imports was US\$8.1, Malaysia was US\$3.9, the Philippines was US\$3.5, Brunei Darussalam was US\$1.6, and Vietnam of US\$93.2 million (CNBC 2017).

Natural gas consumption in Indonesia in 2018 was 1.7 million MMSCF for the industrial sector of feedstock/ energy, electricity generation, city gas (household and commercial), and gas lift (ESDM 2019). In addition, this natural gas is also an export commodity with an annual average of 1.2 million MMSCF in the form of LNG and gas. LPG consumption in 2018 was 7.5 million/tons, supplied from import of 74\% (5.5 million/tons) and domestic production of $26 \%$ ( 2 million/tons). In 2018, the total percentage of LNG exports to natural gas decreased to $40 \%$ compared to 2009 by 50\% as shown in Fig.3.

Conversion of kerosene to LPG by the government has increased the LPG consumption in the community. Meanwhile, the availability of LPG produced domestically is still very limited. Consumption of $3 \mathrm{~kg} \mathrm{LPG}$ continues to increase due to subsidies from the government. Therefore, the government must anticipate this increase since in the implementation, it is considered mistarget.

\subsection{Potential and Implementation RE in Indonesia}

The availability of RE which is quite a lot can replace the dependence of fossil energy. This can be done if the existing RE can be utilized optimally. Thus, the global government's commitment to reduce greenhouse gas emissions can be achieved. As a result, it has encouraged the Government to increase the role of RE sustainably as part of maintaining domestic energy security and independence. Following the Government Regulation No. 79 of 2014 on the National Energy Policy, the target of RE in 2025 is at least $23 \%$ and $31 \%$ in 2050 . Indonesia has very abundant potential of RE to achieve the primary energy mix target.

The total RE potential in Indonesia reached $441.7 \mathrm{GW}$ in 2019 with an installed power of $9.07 \mathrm{GW}$ or only $2 \%$ of the total that can be utilized. Total RE of $441.7 \mathrm{GW}$ is sourced from tidal/wave energy potential of $17.9 \mathrm{GW}$, geothermal of (potential resources $11.0 \mathrm{GW}$, reserve 17.7 GW and realization of PLTP $1.808 \mathrm{GW}$ ), bioenergy of (potential 32.6 GW, BBN $200 \mathrm{Bph}$ and Realization of PLTBio $1.840 \mathrm{GW}$ ), wind power potential of $60.6 \mathrm{GW}$ and realization of PLTB 1.1 MW, and solar power potential of 207.08 GW and realization of PLTS 0.090 GWp show in Fig. 1. While the implementation of RE sources only reached 2\% from geothermal of $1.949 \mathrm{GW}$, bioenergy of $1858 \mathrm{GW}$, wind of $147.01 \mathrm{MW}$, hydro of $5.417 \mathrm{GW}$, and solar power of $0.135 \mathrm{GW}$ as shown in Fig. 1 (PPIPE 2018; RUPTL 2019).

The highest geothermal energy potential is found in Sumatera Utara at $970 \mathrm{MW}$ and followed by West Java at 790 MW. While Aceh Province is ranked third with 590 MW, East Java of 405 MW, Lampung of 395 MW, Maluku of 290 MW, West Sumatera of 270 MW, Bengkulu and Central Java of 245 MW. Meanwhile, the other provinces show geothermal energy potential is below 200 MW as shown in Fig. 4a. The total geothermal energy 


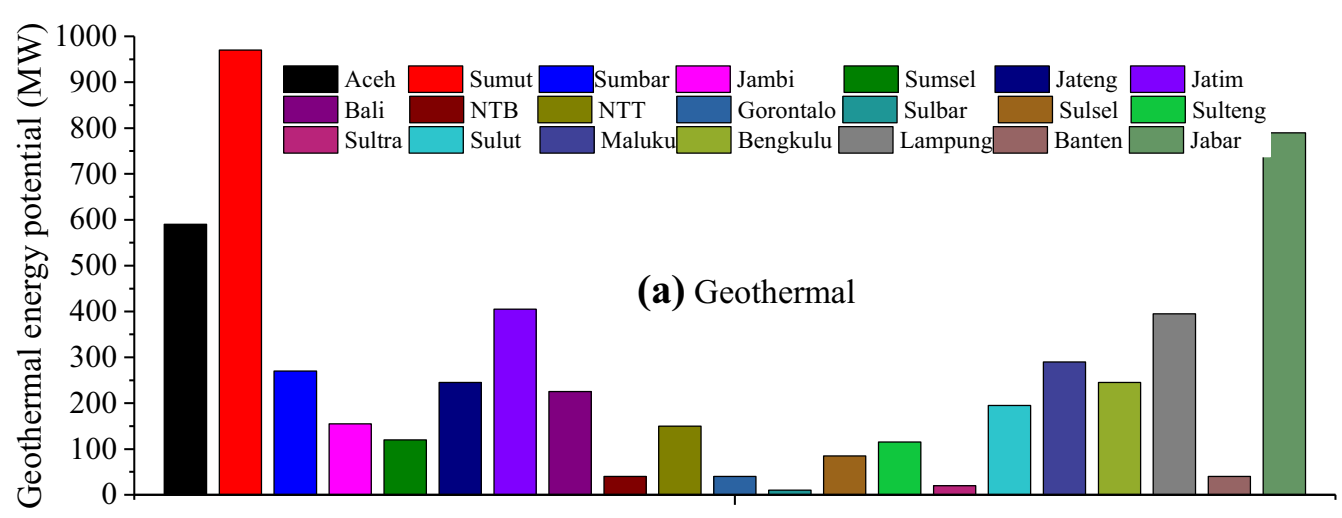

Region Province

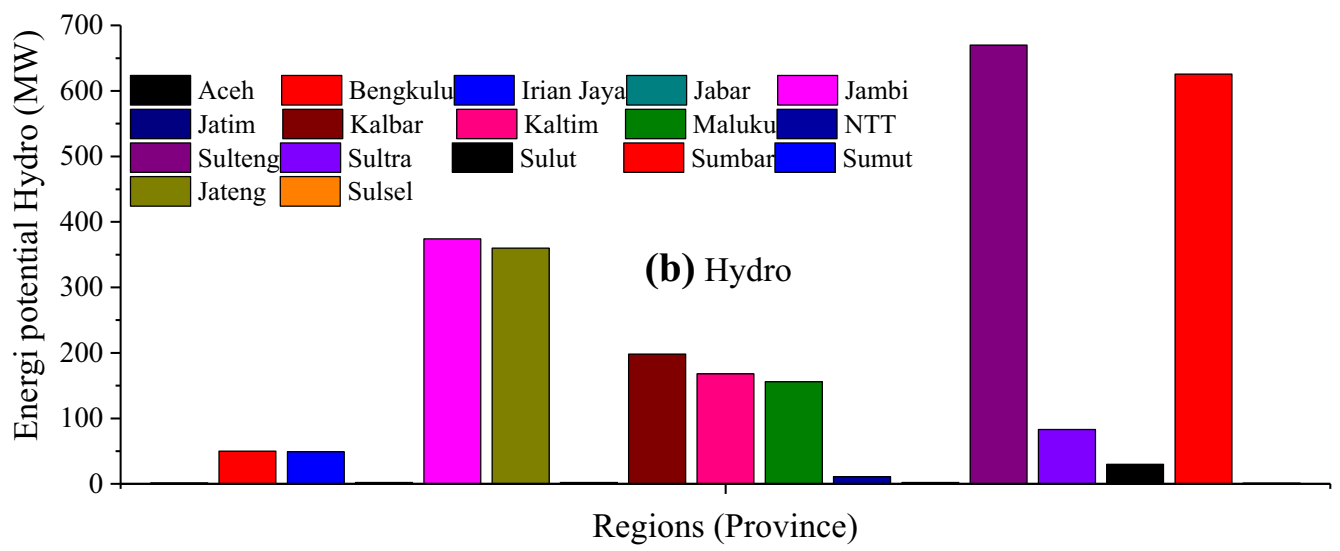

Fig. 4 a, b Total geothermal and hydro potential for the different province in Indonesia

in Indonesia are 5.395 MW spread in 21 provinces (Ppipe 2018; RUPTL 2019).

Total hydroelectric energy potential (PLTA) in Indonesia is $12.281 \mathrm{MW}$ spread in 17 provinces. The highest potentials of hydropower energy are spread in South Sumatera, East Java and West Java, respectively, $2368 \mathrm{MW}, 2168 \mathrm{MW}$, and $2138 \mathrm{MW}$. Meanwhile the Province of Aceh has a hydropower energy potential of $1595 \mathrm{MW}$, Central Sulawesi of $670 \mathrm{MW}$, Jambi of 374 MW, Central Java of 360 MW, West Kalimantan of 198 MW, East Kalimantan of 168 MW, and Maluku of $156 \mathrm{MW}$. Meanwhile, the provinces with a hydropower energy potential below $100 \mathrm{MW}$ are shown in Fig. 4b (Ppipe 2018; RUPTL 2019).

One of the RE sources in Indonesia that cannot be utilized properly is solar energy. The potential of solar energy can be found almost in all provinces in Indonesia. However, the utilization of this energy has not been optimal, even though solar energy can be used as electrical energy, heating, cooling, etc. The highest potential of solar energy is found in the province of West Kalimantan of 20,113 MW. Furthermore, the potentials of solar energy can be found the provinces of South Sumatra, East Kalimantan, and North Sumatera, respectively, 17,233 MW,
13,479 MW, and 11,51 MW. Meanwhile, the least solar energy potentials are found in Jakarta and Bangka Belitung, respectively, $225 \mathrm{MW}$ and $281 \mathrm{MW}$ as shown in Fig. 5. The total utilization of solar energy in Indonesia in 2018 was $0.05 \%$ of the total potential. However, the government's target for the solar energy utilization in 2025 is 1.047 MWp compared to $9442 \mathrm{MWp}$ in 2018 (ESDM 2018).

The total potential of RE in Indonesia such as geothermal, solar, bioenergy, wind, hydro, mini-micro hydro, and tidal/wave reaches 239,970 MW. Meanwhile, the RE installed capacity in 2019 is only $8215.5 \mathrm{MW}$. The total of new RE that can be utilized until 2019 reached $17.452 \%$. It is assumed to be very small compared to the existing potential as shown in Table 1.

The total target of RE development during the period 2019-2028 shows that the use of RE is more dominant. This is because conventional energy reserves (fossil) are running low so the government has to import substantial oil. With the development of RE, the government can reduce oil imports that have continued to soar in recent decades. Development for hydropower energy power plants is the highest compared to other energy. Meanwhile PLTP, PLT Bio-Fuel, PLTMH and PLTS were ranked 


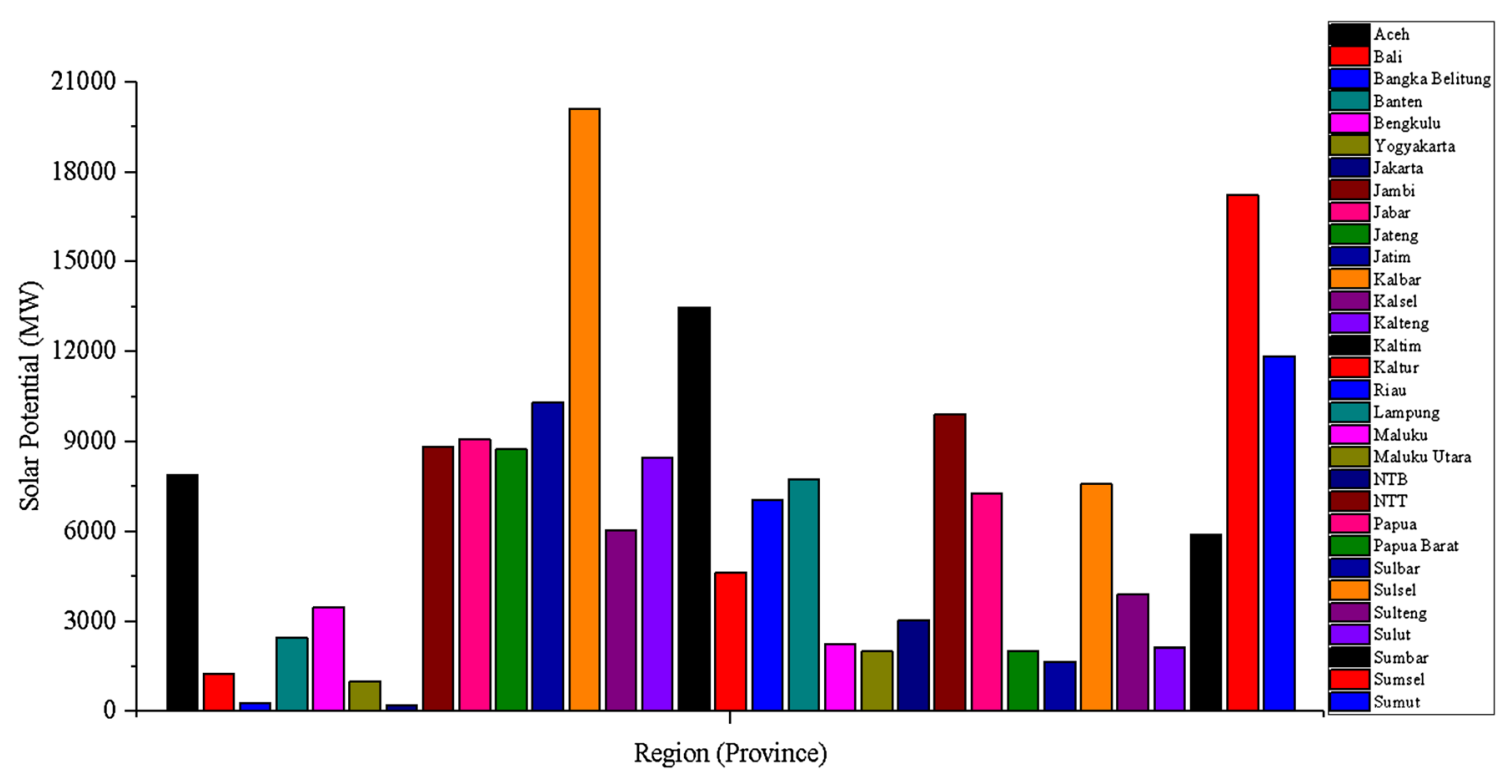

Fig. 5 Solar potential in Indonesia for different Province

Table 1 RE potential, installed and utilization in Indonesia (PLN 2017, 2019)

\begin{tabular}{lccccccc}
\hline Energy type & $\begin{array}{l}\text { Geothermal } \\
(\mathrm{MW})\end{array}$ & Solar (MW) & $\begin{array}{l}\text { Bioenergy } \\
(\mathrm{MW})\end{array}$ & $\begin{array}{l}\text { Wind } \\
(\mathrm{MW})\end{array}$ & $\begin{array}{l}\text { Hydro } \\
(\mathrm{MW})\end{array}$ & $\begin{array}{l}\text { Mini-micro Hydro } \\
(\mathrm{MW})\end{array}$ & $\begin{array}{l}\text { Tidal wave } \\
(\mathrm{MW})\end{array}$ \\
\hline Potential & 29.544 & $\begin{array}{c}4.80 \mathrm{kWh} / \\
\mathrm{m}^{2} / \mathrm{day}\end{array}$ & 32.654 & 60.647 & 75.091 & 19.385 & 17.989 \\
$\begin{array}{c}\text { Installed } \\
\text { capacity }\end{array}$ & 1438.5 & 78.5 & 1671.0 & 3.1 & 4826.7 & 197.4 & 0.3 \\
\begin{tabular}{l} 
Utilization \\
\hline
\end{tabular} & $4.9 \%$ & $0.04 \%$ & $5.1 \%$ & $0.01 \%$ & $6.4 \%$ & $1.0 \%$ & $0.002 \%$ \\
\hline
\end{tabular}

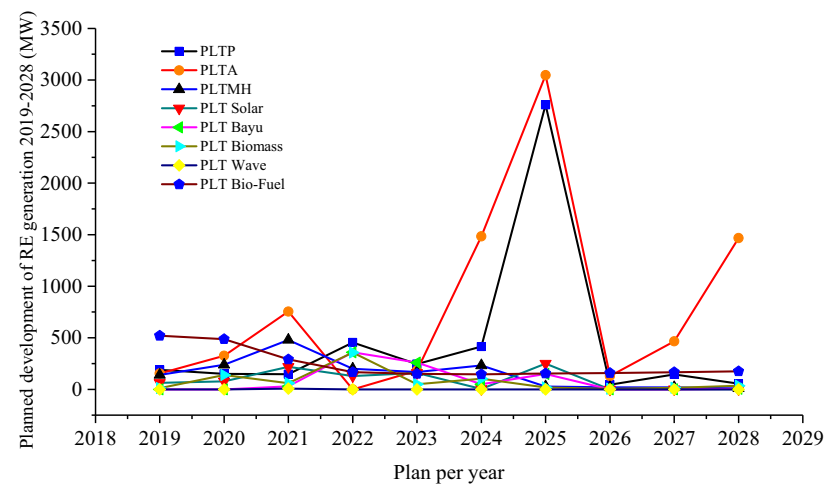

Fig. 6 Total development of RE generation for 2019-2028

second, third, fourth, and five respectively, during the period 2019-2028 as shown in Fig. 6 (ESDM 2019). Meanwhile, in the sixth, seventh and eighth place, respectively PLT Bayu, PLT Biomass and PLT Wave.

$\mathrm{RE}$ development in Indonesia is generally spread in five islands including Sumatra, Kalimantan, Java-Bali, Sulawesi, and Maluku and Papua as shown in Table 2. The highest total capacity target for RE is in Sumatra Island with a total capacity of $8852 \mathrm{MW}$. While the highest potential for RE that has not been utilized during the 2017-2026 period is found in Sulawesi Island at $4155 \mathrm{MW}$. The type of RE for the highest installed capacity is hydropower energy of 12,342 MW. While the potential of hydropower energy that has not been utilized is $6869 \mathrm{MW}$. The total installed capacity of hydropower energy in Java-Bali is higher than Sumatra Island and other islands. However, the potential of hydropower energy during the period 2017-2026 does not exist. Meanwhile, the highest potential of hydropower energy that has not been utilized is in Sulawesi Island of 3852 MW. The total installed capacity of RE in Indonesia until 2026 reaches 21.549 MW and the potential for RE that has not been utilized in the same period is 9.3889 MW (Caraka 2016; Widyaningsih 2017; RUPTL 2019).

Overall, energy sourced from biomass found in 27 provinces in Indonesia is 23,335.07 MW. The most biomass energy sources are in Riau province of 4,169.6 MW and followed by the provinces of North Sumatra and South 


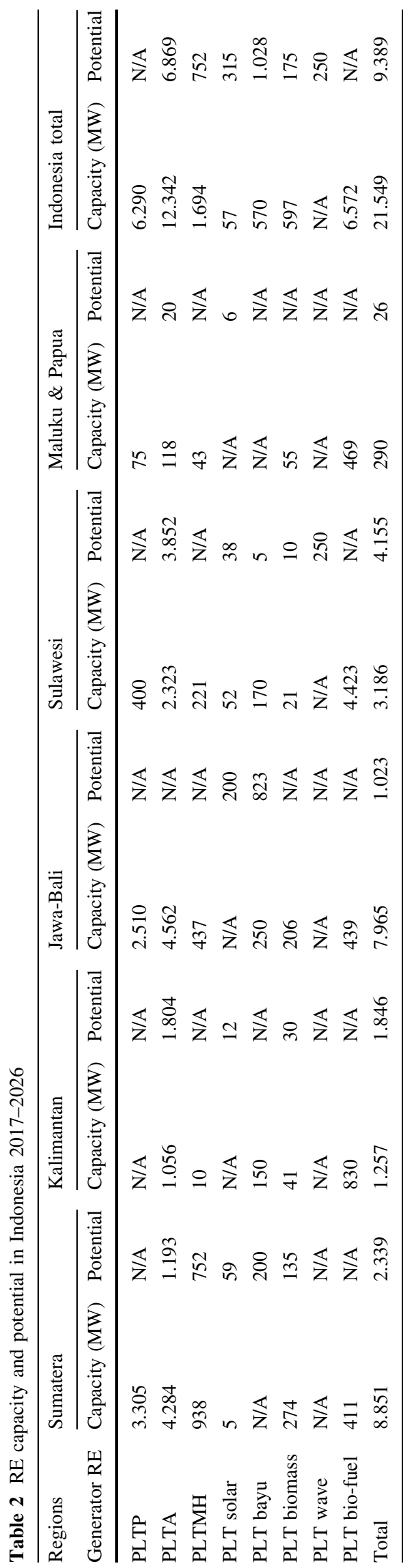

Sulawesi of 2,796.01 MW and 2,061.04 MW, respectively. Meanwhile, the smallest biomass energy source is in Jakarta of 0.5 MW as shown in Fig. 7a. The small potential of biomass in Jakarta is caused by the area of mapping and has been met by housing residents. Whereas for forest areas, it is almost certain that there are no more in Jakarta. Meanwhile, if compared to the forest area in Riau and Sumatra Utara provinces, it is far more than Jakarta. Furthermore, the potential source of biogas energy in Indonesia is also very adequate when used for energy, especially for electricity generation. The first most potential sources of biogas energy are in Jakarta, Banten, and North Sumatera with 126.01 MW, 118.06 MW and 115.05 MW, respectively, as shown in Fig. 7b (Mulyana 2016; Wulandari et al. 2020). The potential for biogas energy in Indonesia in 2016 reached 2,603 MW. The potential of biogas is much smaller than the potential of biomass reaching 30,051 MW. However, it is predicted that the potential of biogas will continue to increase along with the increase in other RE sources, mainly from agricultural products. The high biogas in these three provinces can be due to the high number of the population so that the potential for biogas produced is more than the other provinces.

\subsection{Target RE}

At present, the development of RE refers to Presidential Regulation No. 5 of 2006 on National Energy Policy. It is stated that the contribution of RE in the national primary energy mix in 2025 is 17\% with the composition of Biofuel of 5\%, Geothermal of 5\%, Biomasses, Nuclear, Water, Solar, and Wind $5 \%$, and coal liquefied of $2 \%$. For this reason, the steps to be taken by the Government are to increase the installed capacity of the Micro Hydro Power Plant to $2,846 \mathrm{MW}$ in 2025 , the installed capacity of 180 MW Biomass in 2020, the installed wind capacity (PLT Bayu) of $0.97 \mathrm{GW}$ in 2025, solar 0.87 GW in 2024, and nuclear $4.2 \mathrm{GW}$ in 2024 . The total investment absorbed by RE development until 2025 is projected at USD 13.197 million.

Utilization of solar energy as electricity generation aims to increase national energy security, reduce dependence on the use of fossil fuels, and increase economic investment. In addition, it can make domestic industries are more efficient, reduce greenhouse gas emissions, and meet the government's target of RE use by $23 \%$ by 2025 . The Government of Indonesia has set targets for the use of installed solar energy in 2025 by 1,008.4 MW (Sugiyono 2016; ESDM 2019). The use of the energy mix in 2025 is targeted by the government for coal of $54.6 \%$, natural gas/ LNG of $22 \%$, RE of $23 \%$ and fossil energy of $0.4 \%$. The target for energy use in 2025 is adjusted to government 


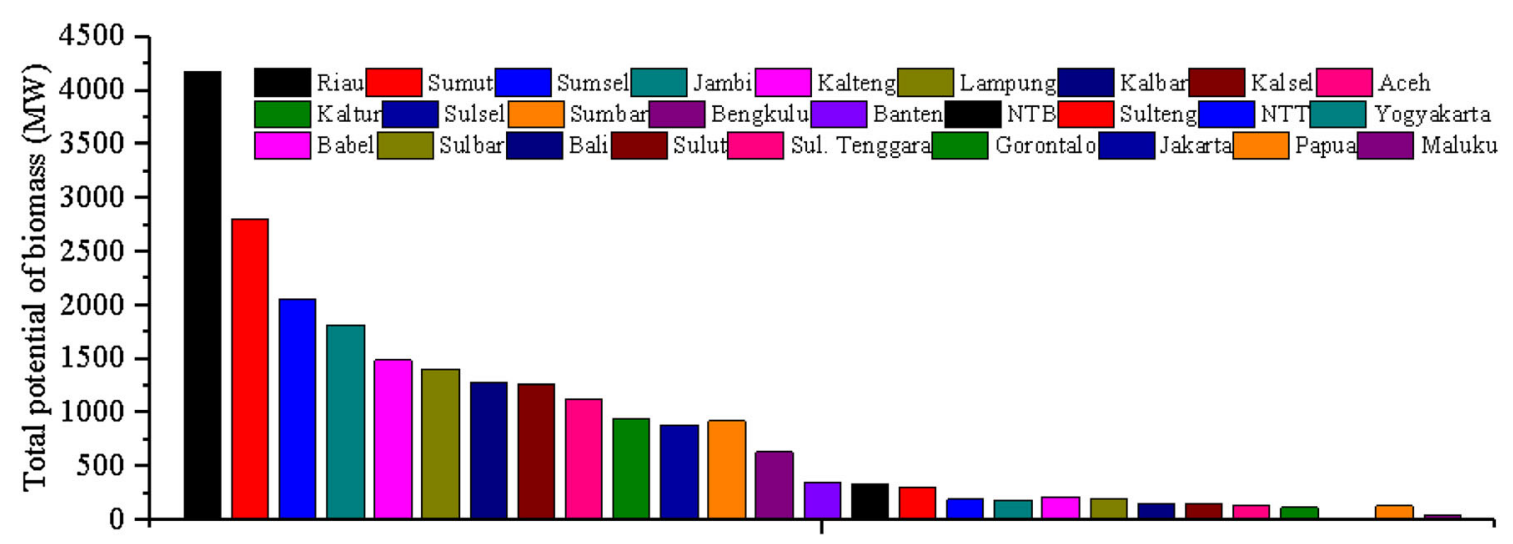

(a) Regions (Province)

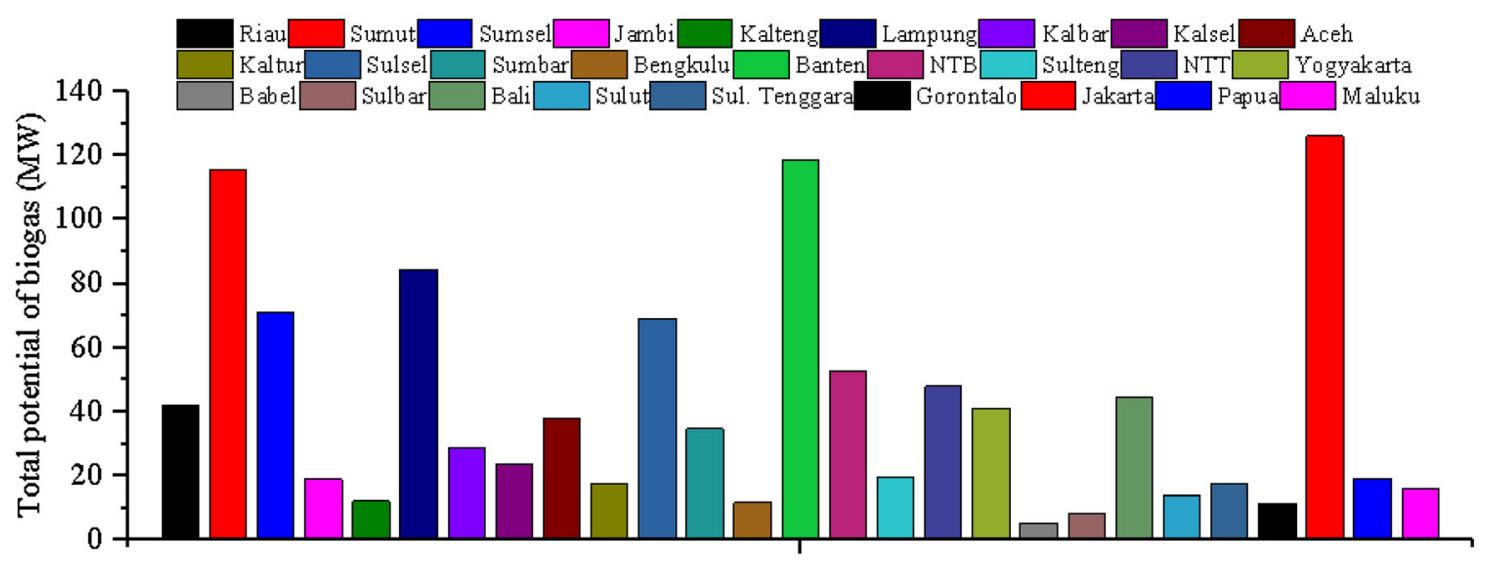

(b) Regions (Province)

Fig. 7 a, bTotal potential RE of biomass and biogas for different province (Mulyana 2016)

policies in utilizing RE and gas, so that dependence on fossil energy can be reduced. The development of RE can be increased until 2028 by seeking to be able to increase the capacity of PV roofs of $3.200 \mathrm{MW}$ for 1.6 million customers. Electricity energy production in 2028 is targeted at $500.691 \mathrm{GWh}$, mostly produced from coal energy of $272,354 \mathrm{GWh}$, gas of $110.150 \mathrm{GWh}$, hydro of 54.736 GWh, Geothermal of 48,217 GWh, RE and fossil energy of 13,205 GWh and 2,019 GWh, respectively, as shown in Fig.8a. Based on the composition of electricity production by type of fuel, the government's target to reduce the use of fossil fuels and reduce imports can be achieved. However, to achieve this target, a strong government policy and adequate resources are needed. Meanwhile, Fig. $8 \mathrm{~b}$ shows the composition of the energy mix for electricity generation. Based on the composition of the power plant using the energy mix, the government's target to reduce greenhouse gas emissions in 2028 can be achieved. Therefore, air pollution caused by industrial fuels and vehicles can be realized. The composition of production and generation with a mixture of energy during the period 2019-2028 is shown in Fig. 8a, b. To be able to support this energy production target, sufficient fuel is needed with adequate availability. If the availability of this fuel is lacking, it is highly unlikely that targets for energy production and emission reductions can be achieved.

The government's RE targets in 2025 and 2050 are 23\% and $31 \%$, respectively, as shown in Fig. 9a, b. It can be seen that the RE target becomes greater than the other energy mix. Meanwhile, the petroleum energy mix will decrease to $20 \%$ by 2050 . The increasing population has driven the increasing demand for energy, especially for transportation and electricity. Meanwhile, fossil energy production (non-renewable) will continue to decline, forcing the government to import petroleum to meet domestic needs. To overcome fossil fuels that continue to experience depletion, the government has made several policies to support the use of RE nationally. The government's target is to meet national energy by building several electricity generators such as geothermal energy, solar energy, and bioenergy, hydropower, and wind power. Besides, the government made policy on the use of biofuels (B20), namely mixing diesel engine fuel with palm oil to 


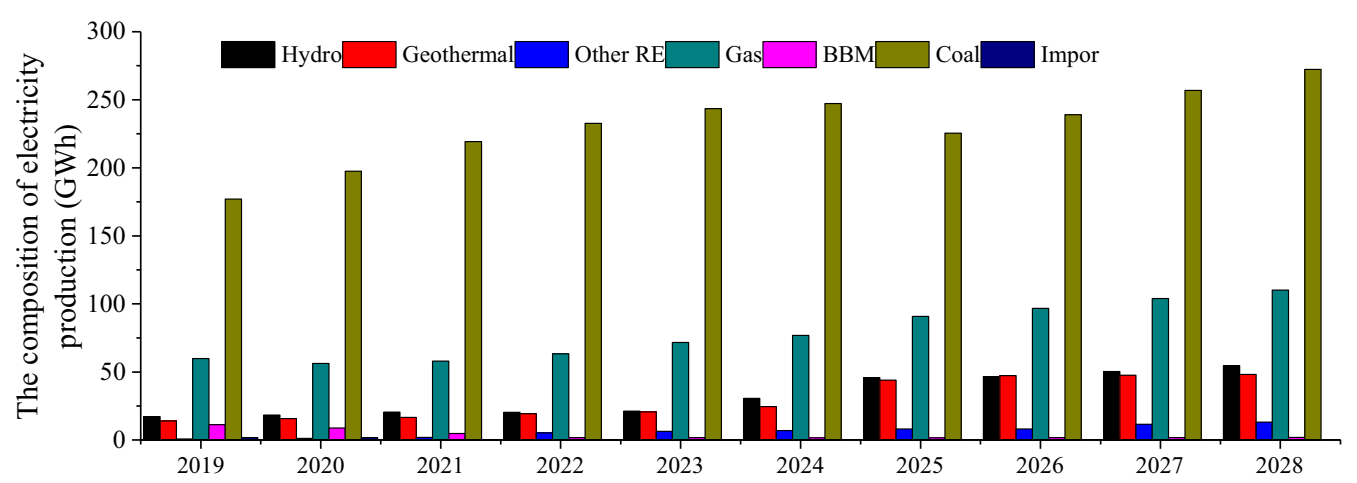

(a) Composition of fuel use per years

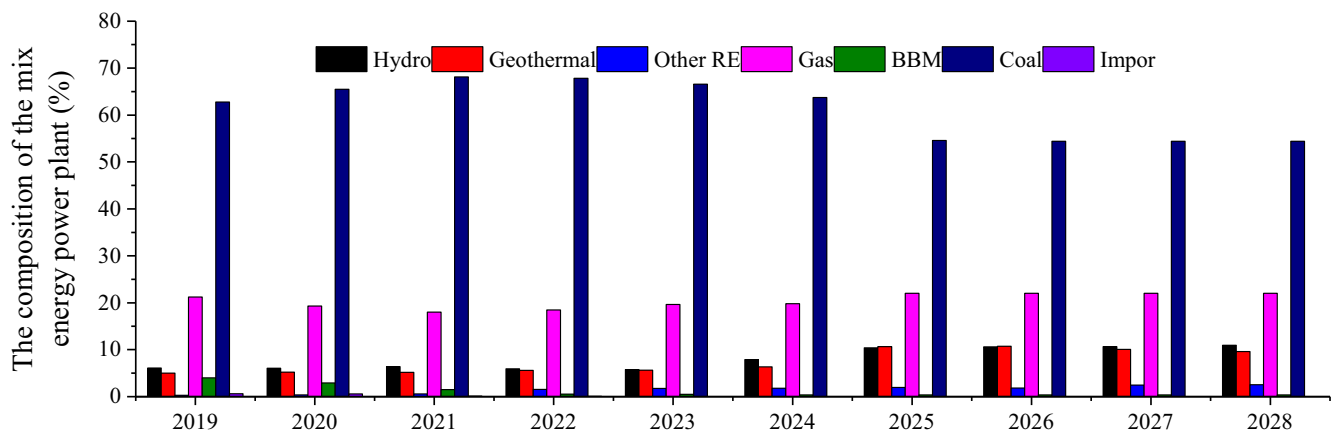

(b) Composition of the mix energy power plant/years

Fig. 8 a Composition of production and $\mathbf{b}$ composition of mix energy

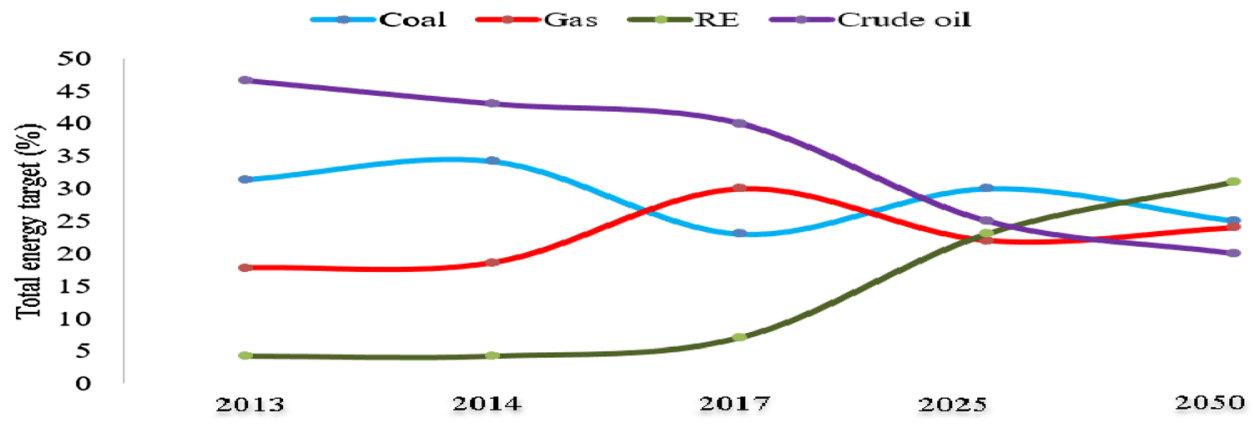

(a) Energy target for 2013-2050

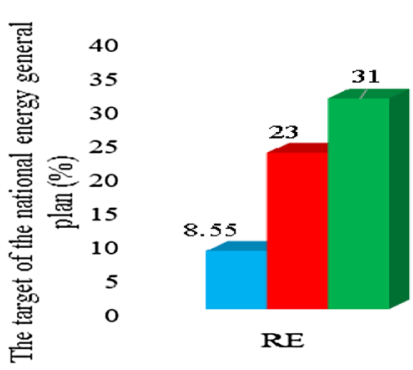

$=2018=2025=2050$

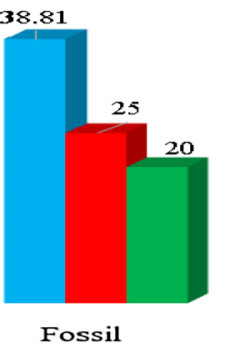

(b) Energy target for

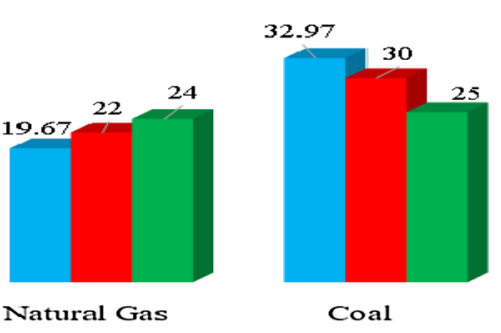

Natural Gas

Fig. 9 a, b Total target RE for years 2013-2050

reduce the use of fossil energy (Sugiyono 2016; PPIPE 2018 Nugroho 2019).

\subsection{Energy demand}

National energy demand in 2050 is targeted at 548.8 MTOE (5.0\%) sourced from the energy mix (EM), 


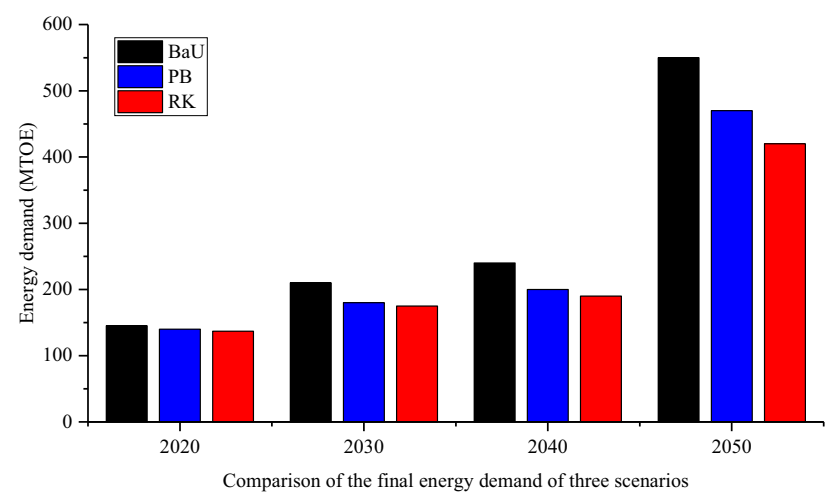

Fig. 10 Comparison of energy demand 2020-2050

sustainable development (SD) of 481.1 MTOE (4.7\%), and low carbon (LC) of 424.2 MTOE (4.3\%). The SD to EM scenario can save final energy reaching $12 \%$ by 2050 . Meanwhile, the final energy demand from the LC scenario to EM can save $23 \%$ by 2050 as shown in Fig. 10 . The total amount of energy demand in 2050 is predicted to be still dominated by the transportation and industrial sector. This is due to industrial growth and the increase in the volume of motor vehicles accompanied by an increase in population which increases every year. Final energy demand by type of energy in 2050 shows that electricity demand will dominate by $35 \%$ (EM), $34 \%$ (SD) and $33 \%$ (LC), respectively (Sugiyono 2016; ESDM 2019). The high demand for electricity can be influenced by the increasing use of electronic devices, especially in the household sector. In addition, the substitution of the use of generators in the industrial and commercial sectors with fuel oil to using electricity on the grid.

Energy demand for the industrial sector in 2050 is estimated to reach 230.9 MTOE sourced from EM, SD of 194.03 MTOE and LC of 157.07 MTOE. The use of energy in this industry is divided into six parts including the cement industry, fertilizer, paper, ceramics, metals, and the food/beverage industry. The total amount of energy demand in the industrial sector reaches $87 \%$. For the transportation sector, energy demand is still dominated by fuels such as diesel, gasoline, biodiesel, bioethanol, gas, avgas, and aviation fuel. The transportation sector consumed $96 \%$ of fuel in 2018 and the rest was supplied by natural gas and biodiesel. The biggest energy demand for transportation in 2018 was dominated by motorcycles, i.e. $41 \%$. Energy demand for air transportation in 2018 also increased and in 2050 demand for aviation fuel is predicted to reach 27.06 MTOE. Energy demand for the trucking sector in 2050 is projected at $43 \%$. For passenger car transportation, although there is an upward trend in energy demand, its growth has been able to be tempered by the use of more efficient technology. Therefore, energy demand in 2050 is projected to increase from 6.07 MTOE in 2018 to 23.07 MTOE in the EM scenario and 21.01 MTOE in the SD scenario and 20.9 MTOE in the LC scenario.

Energy demand in the household sector is affected by the increasing number of households predicted to reach 70.6 million in 2025 and around 80 million in 2050. In addition, the level of urbanization drives future energy demand increases. Based on BPS projections, in 2035, the

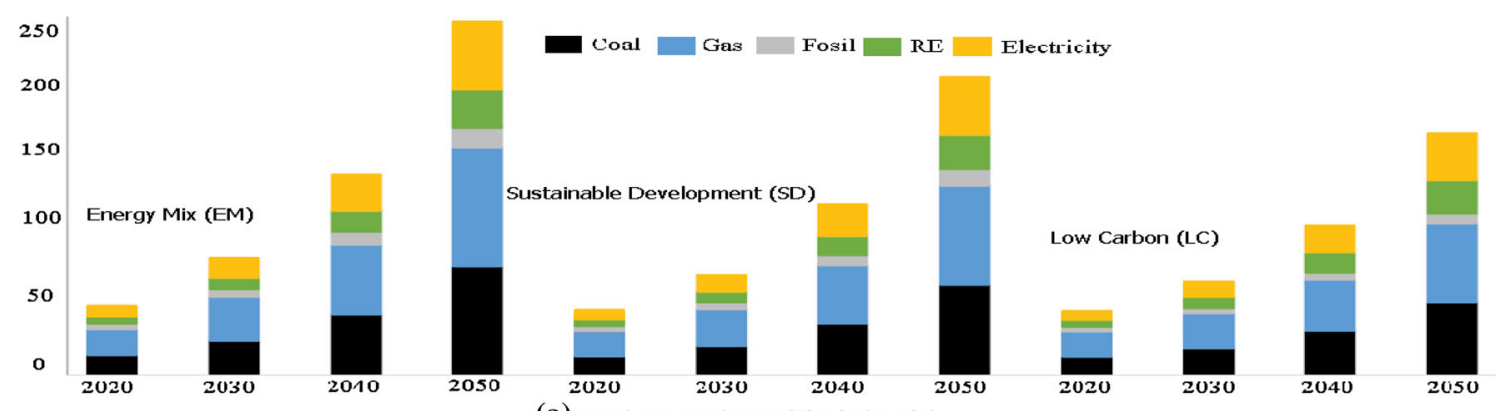

(a) Total energy demand for industrial

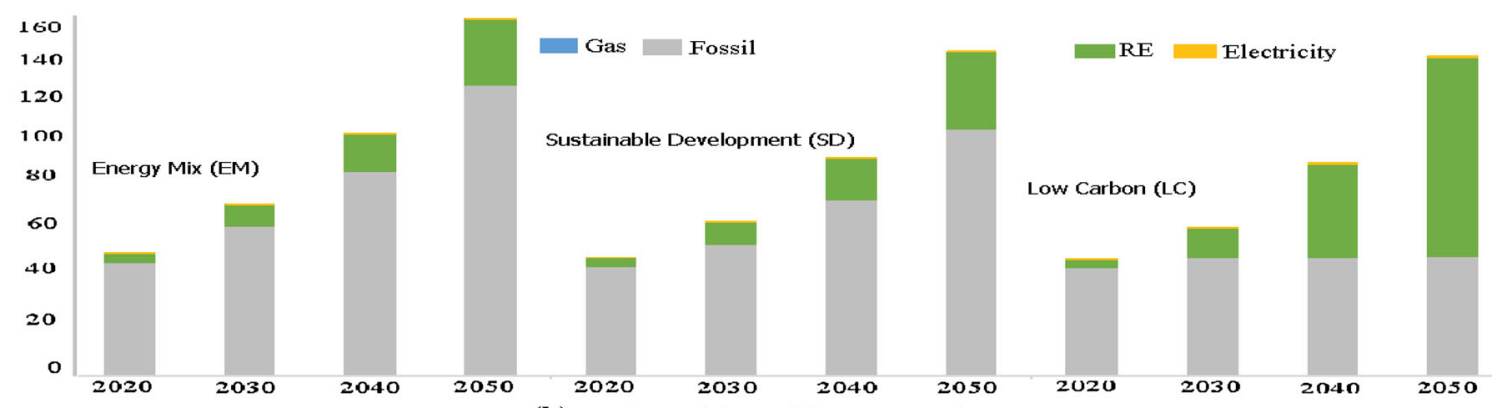

(b) Total energi demand for transportation

Fig. 11 a, b Total energy demand for industrial and transportation 


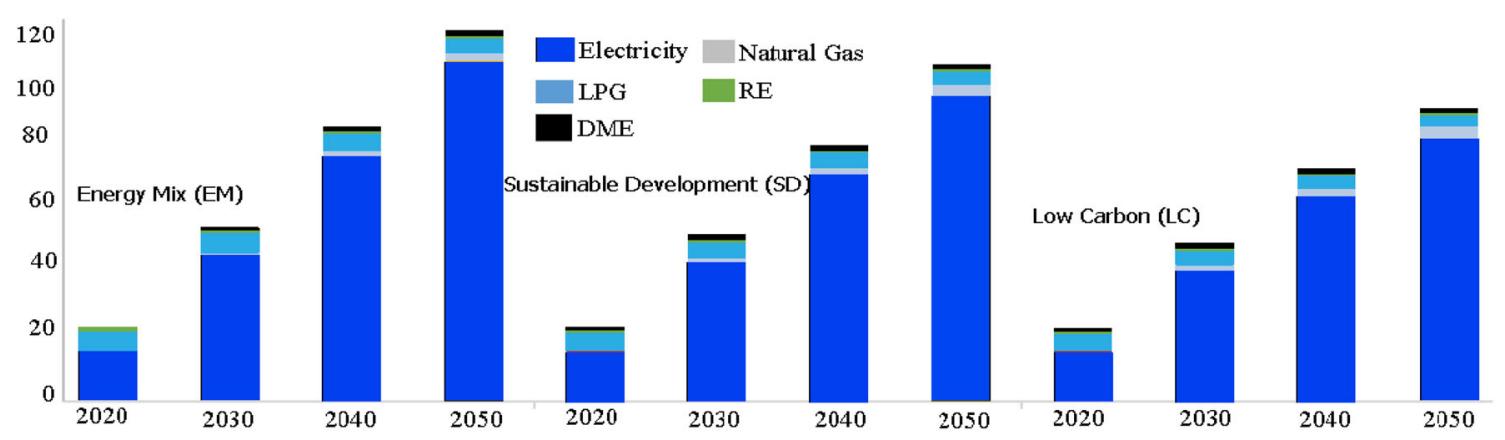

(a) Total energy demand for household

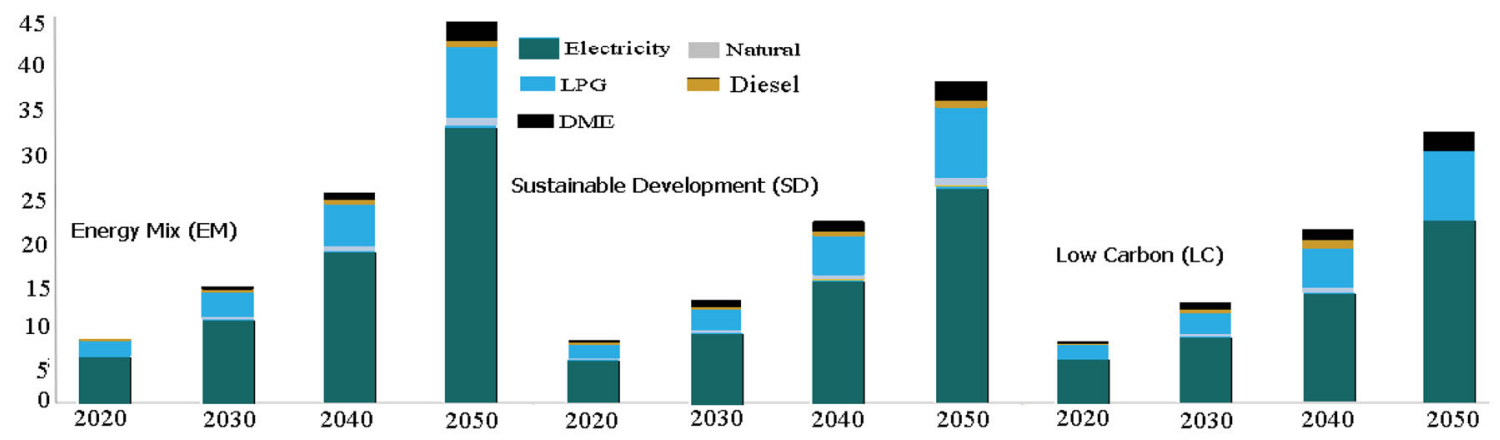

(b) Total energy demand commercial

Fig. 12 a, b Total energy demand for sector household and commercial

urbanization rate can reach $67 \%$ compared to 2010 which was only $49.8 \%$. Energy demand in 2050 for the household sector reaches 120 MTOE (EM), 109 MTOE (SD) and 94.7 MTOE (LC). The dominant use of energy for the household sector in 2050 is electricity. Thus, the share of electricity demand in 2050 is projected to increase by $90 \%$ compared to 2018 which was only $60 \%$. Energy demand for the commercial sector such as offices, hotels, restaurants, hospitals, and other services. The use of energy in the commercial sector such as electricity, LPG, solar, gas, biodiesel, and DME use electricity around 60\%-70\%. Total final commercial energy demand in 2050 is estimated at 47.7 MTOE (EM), 40.5 MTOE (SD), and 36.2 MTOE (LC). In the agriculture, mining, and construction sectors, energy demand is generally sourced from coal, diesel, biodiesel, and electricity. Coal is used in the mining subsector, while diesel and biodiesel are used as generators as electricity supply reserves. In 2018, energy demand for the three mining sectors declined by $43 \%$, while in 2050 , it is projected to decrease to $27 \%$. However, the construction sector is projected to increase from $26 \%$ in 2018 to $42 \%$ in 2050. This was greatly influenced by increased economic growth as the population increases (ESDM 2019; Statistik 2019).

Energy demand in the industrial sector in 2050 is estimated to reach 230.9 MTOE (EM), 194.3 MTOE (SD), and 157.7 MTOE (LC) as shown in Fig. 11a. Meanwhile,

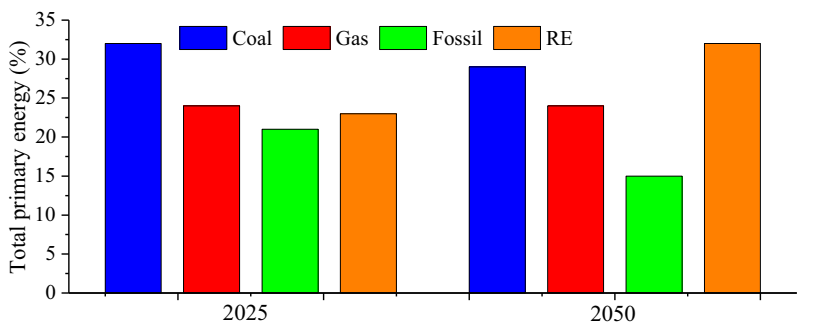

(a) Comparison energy supplay for scenario SD

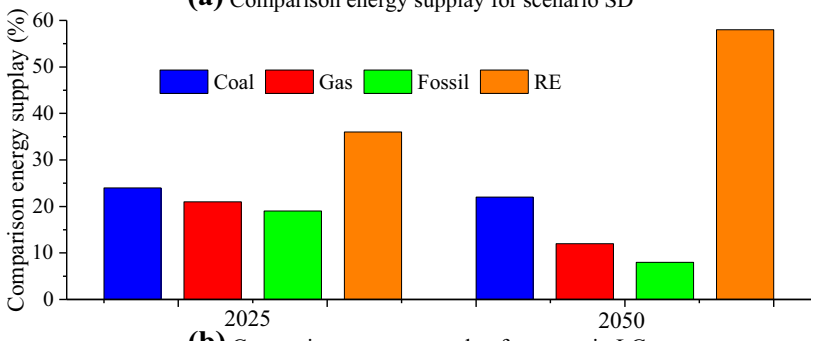

(b) Comparison energy supplay for scenario LC

Fig. 13 a, b Comparison of primary energy for scenario SD and LC

energy demand for transportation in the EM scenario and the sustainable development scenario (SD) shows the share of conventional oil demand until 2050 is still high. However, in the low carbon (LC) scenario, the share of conventional (fossil) oil demand in 2050 is estimated to decrease due to the application of mixing biodiesel by $100 \%$ (green diesel) and bioethanol by $85 \%$. Thus, the share of oil demand in the LC scenario in 2050 becomes 
Table 3 Assumptions and RE scenarios

\begin{tabular}{|c|c|c|c|}
\hline Assumption & Energy mix (EM) & Sustainable development (SD) & Low carbon (LC) \\
\hline Economic growth & $5.6 \%(2045)$ & & \\
\hline Population growth & $0.7 \%(2045)$ & & \\
\hline \multirow[t]{2}{*}{ Biodiesel target } & $20 \%(2025)$ & $30 \%(2025)$ & $30 \%(2025)$ \\
\hline & $30 \%(2050)$ & $30 \%(2050)$ & $100 \%(2050)$ \\
\hline \multirow[t]{2}{*}{ Bioethanol target } & $5 \%(2025)$ & $20 \%(2025)$ & $20 \%(2025)$ \\
\hline & & $50 \%(2050)$ & $85 \%(2050)$ \\
\hline Jargas growth & 4.7 SR (2025) & 1 juta SR/years & $>1$ juta SR/years \\
\hline \multirow{2}{*}{$\begin{array}{l}\text { LPG substitution with electric } \\
\text { induction cooker }\end{array}$} & $0.5 \%(2025)$ & $1 \%(2025)$ & $2 \%(2025)$ \\
\hline & & $2 \%(2050)$ & $5 \%(2050)$ \\
\hline LPG substitution with DME & $20 \%(2025)$ & $20 \%(2025)$ & $20 \%(2025)$ \\
\hline \multirow{2}{*}{$\begin{array}{l}\text { Electric car target (\% of total } \\
\text { population) vehicle) }\end{array}$} & $0.01 \%(2025)$ & $0.01 \%(2025)$ & $0.5 \%(2025)$ \\
\hline & $0.07 \%(2050)$ & $0.24 \%(2050)$ & $1.18 \%(2050)$ \\
\hline $\begin{array}{l}\text { Electric motor target (\% of total } \\
\text { population) vehicle) }\end{array}$ & $1.38 \%(2025)$ & $1.44 \%(2025)$ & $1.18 \%(2025)$ \\
\hline \multirow[t]{4}{*}{ Power plants } & $1.5 \%(2050)$ & $1.7 \%(2050)$ & $3 \%(2050)$ \\
\hline & \multirow{3}{*}{$\begin{array}{l}\text { Electricity supply business } \\
\text { plan (ESBP) }\end{array}$} & RUEN & Emission reduction $>$ RUEN \\
\hline & & $\begin{array}{l}10 \% \text { switching capacity PLTU to } \\
\text { PLT biomass }\end{array}$ & $\begin{array}{l}30 \% \text { switching capacity PLTU to } \\
\text { PLT biomass }\end{array}$ \\
\hline & & $\begin{array}{l}25 \% \text { of luxury homes use solar } \\
\text { rooftop }\end{array}$ & $\begin{array}{l}30 \% \text { of luxury homes use solar } \\
\text { rooftop }\end{array}$ \\
\hline
\end{tabular}

$37 \%$ and the RE demand share increases to $62 \%$ as shown in Fig. 11b. Energy demand for the household sector in 2050 is estimated to reach 323.7 MTOE sourced from 120 MTOE (EM), 109 MTOE (SD), and 94.7 MTOE (LC). The share of electricity demand is estimated to increase from $60 \%$ in 2018 to $90 \%$ in 2050 . The increasing electricity demand is driven by the increasing use of electronic equipment such as air conditioners, refrigerators, water pumping machines, and induction electric stoves. Meanwhile, the demand for LPG in the EM, SD, and LC scenarios in 2050 reached 4.8 MTOE, 4.3 MTOE and 3.4 MTOE as shown in Fig. 12a. In the commercial sector such as offices, hotels, restaurants, hospitals and other services, the demand for energy is dominated by electricity, LPG, diesel, gas, biodiesel, and DME, reaching 60\%-70\%. Electricity consumption is used for air conditioning (AC), water pumping machines, and lighting (lamps). Total final energy demand for the commercial sector in 2050 is estimated to reach 124.4 MTOE sourced from 47.7 MTOE (EM), 40.5 MTOE (SD), and 36.2 MTOE (LC) as shown in Fig. 12b.

\subsection{Energy supply}

In 2050, the primary energy supply is targeted to reach 943 MTOE compared to 2025 at 314 MTOE. The supply of primary energy for power plants is included in the modelling based on the assumption of generating capacity according to the electricity supply business plan (ESBP) which generates the primary energy requirements for each power plant (RUEN 2017; Widyaningsih 2017; ESDM 2019; Mahidin et al. 2020). In this case, 298 MTOE (32\%) is sourced from coal energy. It is expected that the use of coal can increase added value to the process of coal gasification and coal liquefaction. Energy demand sourced from gas pipelines, LNG, and LPG in 2050 is predicted to be 222 MTOE (24\%) of the total primary energy supply. Meanwhile, the supply of RE is around 29\% (275 MTOE) in 2050. The increase in the supply of RE is influenced by the optimization for the utilization of solar cell energy, geothermal energy, biomass, and water that is intended for electricity generation and fuel subsidies in the transportation sector. In the SD scenario, the primary energy supply is smaller than the energy mix (EM) scenario of 828 MTOE in 2050. However, in the SD scenario, the RE energy is greater than the EM scenario, which is $23 \%$ in 2025 and $32 \%$ in 2050 . This figure is following the targets listed in the KEN and RUEN. In the special LC scenario, RE increases significantly by $58 \%$ in 2050 compared to 2025 by $36 \%$. The comparison of the primary energy mix with SD and LC 2025-2050 scenarios is shown in Fig.13a, b. 
Table 4 Risks and challenges in RE projects

\begin{tabular}{|c|c|c|}
\hline Type RE & Risk issues & Risk management consideration \\
\hline Biomass & $\begin{array}{l}\text { Availability/variability of fuel supply } \\
\text { Variability in resource prices } \\
\text { Environmental obligations are related to fuel handling and } \\
\text { storage }\end{array}$ & $\begin{array}{l}\text { Long-term contracts can solve resource problems. } \\
\text { Fuel handling costs } \\
\text { Emission control }\end{array}$ \\
\hline Biogas & $\begin{array}{l}\text { Resource risks (e.g. reduction in quantity and quality of gas due } \\
\text { to changes in organic raw materials) } \\
\text { Opposition planning is related to the smell problem }\end{array}$ & $\begin{array}{l}\text { Strict safety procedures are needed such as loss control such as } \\
\text { firefighting equipment and services } \\
\text { High level of wear }\end{array}$ \\
\hline Wind & $\begin{array}{l}\text { Long waiting times and upfront costs (e.g. permit planning and } \\
\text { construction costs) } \\
\text { Failure of important components (e.g. gear train/box, bearings, } \\
\text { blades etc.) } \\
\text { Variability of wind resources } \\
\text { Offshore cabling }\end{array}$ & $\begin{array}{l}\text { Turbine makes and models } \\
\text { Manufacturing guarantees from component suppliers } \\
\text { Good wind source data } \\
\text { Loss control e.g. Firefighting can be difficult if the location is } \\
\text { off the coast or altitude } \\
\text { Development of procedures that are generally used }\end{array}$ \\
\hline Tidal/wave & $\begin{array}{l}\text { Survival in a harsh marine environment } \\
\text { Various designs and concepts but without a clear winner } \\
\text { Prototype/technology risk } \\
\text { Small scale and long waiting time }\end{array}$ & $\begin{array}{l}\text { Most of the prototypes and technology demonstration projects } \\
\text { Good resource measurement data }\end{array}$ \\
\hline Geothermal & $\begin{array}{l}\text { Drilling costs and risks that arise (blow out) } \\
\text { Exploration risk (unexpected temperature) } \\
\text { Important components that are damaged, such as pumps } \\
\text { Long waiting time (permission) }\end{array}$ & $\begin{array}{l}\text { Limited operator experience and different aspects of } \\
\text { technology at different locations } \\
\text { Limited sources of measurement data } \\
\text { Agreement on planning can be difficult } \\
\text { 'Technology stimulation' is still unproven but can reduce the } \\
\text { risk of exploration }\end{array}$ \\
\hline $\begin{array}{l}\text { Solar } \\
\text { thermal }\end{array}$ & $\begin{array}{l}\text { Prototype/technology risks as project size increases and is } \\
\text { combined with others. } \\
\text { RETs, for example, solar towers }\end{array}$ & $\begin{array}{l}\text { Good operating history (already since 1984) } \\
\text { Maintenance can be neglected (especially in developing } \\
\text { countries) }\end{array}$ \\
\hline $\begin{array}{l}\text { Small } \\
\text { hydro }\end{array}$ & $\begin{array}{l}\text { Flood } \\
\text { Seasonal/annual source variability }\end{array}$ & $\begin{array}{l}\text { Prolonged damage due to off-site monitoring (long response } \\
\text { time) and lack of spare parts }\end{array}$ \\
\hline PV & $\begin{array}{l}\text { Component damage (e.g. short-circuit current) } \\
\text { Weather damage } \\
\text { Theft/vandalism }\end{array}$ & $\begin{array}{l}\text { Performance guarantees are available (for example up to } \\
25 \text { years) } \\
\text { Standard components, with easy substitution } \\
\text { Maintenance can be neglected (especially in developing } \\
\text { countries) }\end{array}$ \\
\hline
\end{tabular}

\subsection{Economic growth}

Indonesia's economic growth in 2017 and 2018 were $5.07 \%$ and $5.17 \%$, respectively, as reported in the data from the Central Statistics Agency (CSA) (BPS 2019b). In 2019, it increased to 5.3\% and in 2045 it is targeted at $5.6 \%$. ESBP stated that Indonesia's economic growth uses BAPPENAS scenario in 2028 of $6.45 \%$ (RUPTL 2019). This is one of the factors to consider in making scenarios of long-term domestic energy demand. Economic growth statistics are accompanied by energy demand in general.

Energy demand is closely related to economic activity, so the assumption of economic growth will be very sensitive to energy demand from the three scenarios developed as shown in Table 3. Indonesia's economic growth during the 2013-2018 period tended to decrease from 5.6\%$5.17 \%$ as a result of the global economic downturn due to financial market uncertainty and declining trade volume at the world level. The assumption of economic growth is adjusted to the "Vision of Indonesia 2045" published by BAPPENAS (Nasional and Nasional 2017; Garuda 2018). The Indonesia's economic growth in the next few years is supported by rising domestic needs, including consumption and investment, as well as better export growth including in the manufacturing sector which is a major energy consumer in the industrial sector. 


\subsection{RE policy}

To accelerate the development of RE, the Government of Indonesia has established several regulations or policies which are considered to be very supportive:

(1) The Government of Indonesian issued two policies in 2014 and 2017 concerning national energy and national energy general plans through Presidential Regulation numbers 79/2014 and 22/2017, respectively (Widyaningsih 2017).

(2) Presidential Regulation No. 4 of 2016 (Article 14) on the Acceleration of Electricity Infrastructure. The government mandates to be able to implement and accelerate the development of electricity infrastructure by prioritizing the use of RE (Ublik 2016).

(3) Central and Local Governments can provide support in the form of fiscal incentives, licensing, and nonlicensing facilities. Besides determining the purchase price of electricity from each type of RE source, the establishment of a separate business entity in the context of supplying electricity to be sold to PT. PLN (Persero), and/or providing subsidies.

(4) Presidential Regulation No. 66 of 2018 on the Second Amendment to Presidential Regulation No. 61 of 2015 on Collecting and Using Palm Oil Plantation Funds, which require the use of biodiesel for PSO and non-PSO following article 18 paragraph (1b) (Setmilpres 2018).

(5) Minister of Finance Regulation No. 177/PMK.011/ 2007 on Exemption of Import Duties on Imported Goods for Upstream Oil and Gas and Geothermal Business Activities (Khadijah 2018).

(6) Minister of Finance Regulation No. 03/PMK.011/ 2012 on Procedures for Management and Accountability of Geothermal Fund Facilities (Khadijah 2018).

(7) Minister of Energy and Mineral Resources Regulation No. 49 of 2017 is an improvement to the Minister of Energy and Mineral Resources Regulation No. 10 of 2017 on Principles of Electricity Sales and Purchase Agreement (ESDM 2017).

(8) Minister of Energy and Mineral Resources Regulation No. 50 of 2017 is a revision of the Minister of Energy and Mineral Resources Regulation No. 12 of 2017 on Utilization of RE Sources for Electricity Supply, which is issued to create a better business climate while still encouraging efficiency practices and realizing reasonable and affordable electricity prices.

(9) Minister of Energy and Mineral Resources Regulation No. 49 of 2018 on the Use of Roof Solar Power
Table 5 Comparison of selling prices of RE and conventional energy (Lauranti and Djamhari 2017; Mahidin et al. 2020)

\begin{tabular}{lll}
\hline Type of fuels & $\begin{array}{l}\text { Production price } \\
\text { (USD/MW) }\end{array}$ & $\begin{array}{l}\text { Selling price } \\
\text { (USD/kWh) }\end{array}$ \\
\hline $\begin{array}{l}\text { Solar power generation } \\
\begin{array}{l}\text { Mini-hydro/micro-hydro } \\
\text { power plant }\end{array}\end{array}$ & $\begin{array}{l}1.9 \text { million } \\
2 \text { million }\end{array}$ & $\begin{array}{l}0.081-0.06 \\
0.044-0.04\end{array}$ \\
$\begin{array}{l}\text { Wind power plant } \\
\text { Biomass power plant }\end{array}$ & 638 thousand & 0.06 \\
Biomass palm oil & 1 million & 0.07 \\
Biogas power plant & 2.1 million & 0.053 \\
Coal-fired power plant & 1.5 million & $0.086-0.05$ \\
Energy conventional (diesel) & 750 thousand & 0.045 \\
\hline
\end{tabular}

Generation Systems by Consumers of PT. Perusahaan Listrik Negara (PLN).

KEN mandates for RE mix target in the primary energy mix of at least $23 \%$ by 2025 and minimizes the use of petroleum less than $25 \%$ by 2025 . In addition, energy efficiency is also targeted to decrease by $1 \%$ per year to encourage savings in energy use in all sector. Some targets in the KEN which are also considered in the projected energy demand include optimization of the use of natural gas for domestic use and priority use of fossil energy for national industrial raw materials. This policy is implemented to maximize the use of RE, minimize the use of petroleum, optimize the use of natural gas and RE, use coal as a mainstay of national energy supply, and use nuclear as a last resort. With the regulations set by the government, it is expected that the developers (investors) can work better and the targets set can be achieved.

\subsection{Risks and challenges RE}

In the construction of RE project, investors sometimes need to evaluate the risks that may arise when construction or operations begin. Each RE project has different types of risks and obstacles (Goh et al. 2014). A study conducted by the United Nations Environment Program (UNEP) elaborates some of the risks that are generally inherent in the development of RE projects as shown in Table 4 (Gray 1990; Holdren et al. 2000).

\subsection{The electricity selling price}

The price of electricity sales to customers from RE is cheaper compared to conventional energy as shown in Table 5. Meanwhile, the cost of conventional energy 
production is cheaper than RE, except for the production of wind power plants. However, RE has more advantages than conventional energy. The benefits of include environment friendly, more lace emission, reusable, sustainable, and lower operational costs. Meanwhile, conventional energy has higher operational costs compared to RE despite lower production costs. In addition, conventional energy produces higher emissions than RE.

\section{Conclusions}

Investigation of the potential for RE regarding the amount of utilization, energy demand, and the target of power plant construction during the period of 2017-2050 has been completed. Various findings have been presented and discussed earlier so that conclusions can be drawn as follows:

(1) The target of electric energy production in 2028 is $500,691 \mathrm{GWh}$ sourced from 272,354 GWh, gas of $110,150 \mathrm{GWh}$, hydro of 54,736 GWh, geothermal of 48,217 GWh, RE and fuel energy of 13,205 GWh and $2019 \mathrm{GWh}$, respectively. The government of Indonesia is targeting the use of RE by $23 \%$ in 2025 to $31 \%$ in 2050 .

(2) Demand of national energy in 2050 is estimated at 1545.1 MTOE sourced from EM of 548.8 MTOE (5.0\%), SD of 481.1 MTOE (4.7\%), and LC of 424.2 MTOE (4.3\%).

(3) By using RE, economic growth is targeted to increase to $5.6 \%$ in 2045 compared to 2019 of $5.3 \%$.

(4) The policy set by the government in supporting the development of RE to achieve the target of energy use by $23 \%$ in 2025 and to reduce the use of petroleum by $25 \%$ in 2050 .

(5) Time of permit issuance, construction price, resource price, intimidation, etc. is a risk commonly faced by investors in the development of RE.

Open Access This article is licensed under a Creative Commons Attribution 4.0 International License, which permits use, sharing, adaptation, distribution and reproduction in any medium or format, as long as you give appropriate credit to the original author(s) and the source, provide a link to the Creative Commons licence, and indicate if changes were made. The images or other third party material in this article are included in the article's Creative Commons licence, unless indicated otherwise in a credit line to the material. If material is not included in the article's Creative Commons licence and your intended use is not permitted by statutory regulation or exceeds the permitted use, you will need to obtain permission directly from the copyright holder. To view a copy of this licence, visit http://creativecommons. org/licenses/by/4.0/.

\section{References}

Alam MM, Murad MW (2020) The impacts of economic growth, trade openness and technological progress on renewable energy use in organization for economic co-operation and development countries. Renew Energy 145:382-390. https://doi.org/10.1016/j. renene.2019.06.054

Alhamri RZ, Suryani E (2016) Kajian Potensi Energi Panas Bumi sebagai Alternatif Pembangkit Energi Listrik Terbarukan: Sebuah Framework Sistem Dinamik. SISFO 5(5):5

Alola AA, Bekun FV, Sarkodie SA (2019) Dynamic impact of trade policy, economic growth, fertility rate, renewable and nonrenewable energy consumption on ecological footprint in Europe. Sci Total Environ 685:702-709. https://doi.org/10. 1016/j.scitotenv.2019.05.139

Ben Jebli M, Farhani S, Guesmi K (2020) Renewable energy, $\mathrm{CO}_{2}$ emissions and value added: empirical evidence from countries with different income levels. Struct Chang Econ Dyn. https://doi. org/10.1016/j.strueco.2019.12.009

BPS (2019a) Volume Impor Minyak dan Gas Indonesia (1996-2018). https://databoks.katadata.co.id/datapublish/2019/05/24/berapavolume-impor-minyak-indonesia

BPS (2019b) STATISTIK Pertumbuhan Ekonomi Ber Resmi Stat No. 15/02/:1-12

Caraka RE (2016) Simulasi Kalkulator Energi Baru Terbarukan (EBT) Guna Memenuhi Ketahanan Energi di Indonesia. Stat J Theor Stat Its Appl 16:77-88

Charfeddine L, Kahia M (2019) Impact of renewable energy consumption and financial development on $\mathrm{CO}_{2}$ emissions and economic growth in the MENA region: a panel vector autoregressive (PVAR) analysis. Renew Energy 139:198-213. https:// doi.org/10.1016/j.renene.2019.01.010

CNBC. Negara Importir Minyak Terbesar di Asia Tenggara (News 2017) https://www.cnbcindonesia.com/news/201807101018444-22763/wah-ri-ternyata-importir-minyak-terbesar-ketiga-diasean

Deendarlianto WA, Widodo T, Handika I, Chandra Setiawan I, Lindasista A (2020) Modelling of Indonesian road transport energy seetsctor in order to fulfill the national energy and oil reduction targ. Renew Energy 146:504-518. https://doi.org/10. 1016/j.renene.2019.06.169

Erdiwansyah M, Mamat R, Sani MSM, Khoerunnisa F, Kadarohman A (2019a) Target and demand for renewable energy across 10 ASEAN countries by 2040. Electr J 32:106670. https://doi.org/ 10.1016/J.TEJ.2019.106670

Erdiwansyah, Mamat R, Sani MSM, Sudhakar K (2019b) Renewable energy in Southeast Asia: policies and recommendations. Sci Total Environ. https://doi.org/10.1016/j.scitotenv.2019.03.273

Erdiwansyah, Mamat R, Sani MSM, Sudhakar K, Kadarohman A, Sardjono RE (2019c) An overview of Higher alcohol and biodiesel as alternative fuels in engines. Energy Rep 5:467-479. https://doi.org/10.1016/j.egyr.2019.04.009

Eren BM, Taspinar N, Gokmenoglu KK (2019) The impact of financial development and economic growth on renewable energy consumption: empirical analysis of India. Sci Total Environ 663:189-197. https://doi.org/10.1016/j.scitotenv.2019. 01.323

ESDM (2017) Peraturan Menteri Energi dan Sumber Daya Mineral Nomor 49 Tahun 2017

ESDM (Utilization of Solar Energy Sources in Indonesia is Still Very Small. Statement 2018) https://ekonomi.kompas.com/read/2018/ 07/16/164127926/esdm-pemanfaatan-sumber-energi-surya-diindonesia-masih-sangat-kecil

ESDM. Indonesia Energy Out Look (2019) J Chem Inf Model 53:1689-1699. https://doi.org/10.1017/CBO9781107415324.004 
Garuda M (2018) Indonesia 2045 Bentang Pustaka

Goh HH, Lee SW, Chua QS, Goh KC, Kok BC, Teo KTK (2014) Renewable energy project: project management, challenges and risk. Renew Sustain Energy Rev 38:917-932

Gozgor G, Mahalik MK, Demir E, Padhan H (2020) The impact of economic globalization on renewable energy in the OECD countries. Energy Policy 139:111365. https://doi.org/10.1016/j. enpol.2020.111365

Gray MA (1990) The United Nations Environment Programme: an assessment. Envtl L 20:291

Holdren JP, Smith KR, Kjellstrom T, Streets D, Wang X, Fischer S (2000) Energy, the environment and health. New York United Nations Dev Program

Indra Al Irsyad M, Halog A, Nepal R, Koesrindartoto DP (2020) Economical and environmental impacts of decarbonisation of Indonesian power sector. J Environ Manage 259:109669. https:// doi.org/10.1016/j.jenvman.2019.109669

Jenniches S (2018) Assessing the regional economic impacts of renewable energy sources-a literature review. Renew Sustain Energy Rev 93:35-51

Kennedy SF (2018) Indonesia's energy transition and its contradictions: emerging geographies of energy and finance. Energy Res Soc Sci 41:230-237. https://doi.org/10.1016/j.erss.2018.04.023

Khadijah NS (2018) Analisis Pembangunan Pembangkit Listrik Tenaga Panas Bumi (PLTP) Melalui Insentif Fiskal dalam Mendukung Ketahanan Energi Indonesia. Ketahanan Energi 2018:3

Khanna N, Fridley D, Zhou N, Karali N, Zhang J, Feng W (2019) Energy and $\mathrm{CO}_{2}$ implications of decarbonization strategies for China beyond efficiency: modeling 2050 maximum renewable resources and accelerated electrification impacts. Appl Energy 242:12-26. https://doi.org/10.1016/j.apenergy.2019.03.116

Kusumadewi TV, Limmeechokchai B (2017) $\mathrm{CO}_{2}$ Mitigation in residential sector in Indonesia and Thailand: potential of renewable energy and energy efficiency. Energy Proc 138:955-960. https://doi.org/10.1016/j.egypro.2017.10.086

Lauranti M, Djamhari EA (2017) Transisi Energi yang Setara di Indonesia: Tantangan dan Peluang

Liu R, He L, Liang X, Yang X, Xia Y (2020) Is there any difference in the impact of economic policy uncertainty on the investment of traditional and renewable energy enterprises? A comparative study based on regulatory effects. J Clean Prod 255:120102. https://doi.org/10.1016/j.jclepro.2020.120102

Maulidia M, Dargusch P, Ashworth P, Ardiansyah F (2019) Rethinking renewable energy targets and electricity sector reform in Indonesia: a private sector perspective. Renew Sustain Energy Rev 101:231-247. https://doi.org/10.1016/j.rser.2018.11. 005

Mulyana R (2016) Pedoman Investasi Bioenergi di Indonesia

Mahidin S, Erdiwansyah H, Hayati H AP, et al (2020) Analysis of power from palm oil solid waste for biomass power plants: a case study in Aceh Province. Chemosphere 2020:126714. https:// doi.org/10.1016/j.chemosphere.2020.126714
Nasional MPP, Nasional KBPP (2017) Visi Indonesia 2045 Disampaikan Di Jakarta Pada Orasi Ilm Fak Ekon Dan Bisnis Univ Indones 2017

Nugroho H (2019) Indonesia's energy development: evaluation of the 2015-2019 medium term development plan and outlook for that of 2020-2024. Indones J Dev Plan 3:266-272

O’Ryan R, Nasirov S, Álvarez-Espinosa A (2020) Renewable energy expansion in the Chilean power market: a dynamic general equilibrium modeling approach to determine $\mathrm{CO}_{2}$ emission baselines. J Clean Prod 247:119645. https://doi.org/10.1016/j. jclepro.2019.119645

PLN PT (2017) Rencana Usaha Penyediaan Tenaga Listrik (RUPTL) PLN 2017

PLN PT (2019) RUPTL: Rencana Usaha Penyediaan Tenaga Listrik 2019-2028. Indones PT PLN Persero 2019

PPIPE B (2018) Outlook Energi Indonesia 2018: Energi Berkelanjutan untuk Transportasi Darat. Development 2018:134

Purwanto WW, Muharam Y, Pratama YW, Hartono D, Soedirman H, Anindhito R (2016) Status and outlook of natural gas industry development in Indonesia. J Nat Gas Sci Eng 29:55-65

Rahardjo I, Fitriana I (2005) Analisis Potensi Pembangkit Listrik Tenaga Surya di Indonesia. Strateg Penyediaan List Nas Dalam Rangka Mengantisipasi Pemanfaat PLTU Batubara Skala Kecil, PLTN, Dan Energi Terbarukan, P3TKKE, BPPT

RUEN (2017) Target RUEN Dan Kebutuhan Investasi Sub Sektor Energy Fosil 2017:6

RUPTL (2019) Electricity supply business plan. Rencana Usaha Penyediaan Tenaga List 2019:2019-2028

Santika WG, Anisuzzaman M, Simsek Y, Bahri PA, Shafiullah GM, Urmee T (2020) implications of the sustainable development goals on national energy demand: the case of Indonesia. Energy 196:117100. https://doi.org/10.1016/j.energy.2020.117100

Setmilpres (2018) Salinan Peraturan Presiden Republik Inoonesia No 66/2018 2018:1-9

Statistik BP (2019) Ekonomi Indonesia 2018 Tumbuh 5, 17\%. Diperoleh Pada 2019:1

Sugiyono A (2016) Outlook Energi Indonesia 2015-2035: Prospek Energi Baru Terbarukan. J Energi Dan Lingkung 12:87-96

Ublik EP (2016) Peraturan Presiden tentang Percepatan Pembangunan Infrastruktur

Widyaningsih GA (2017) Peraturan Presiden Nomor 22 Tahun 2017 tentang Rencana Umum Energi Nasional. J Huk Lingkung Indones 4:139-152

Wulandari S, Sumanto S, Saefudin S (2020) Pengelolaan Biomassa Tanaman dalam Bioindustri Perkebunan Mendukung Pengembangan Bienergi Plant Biomass Management in Plantations Bioindustry Supporting Bioenergy Development. Perspektif 18:135-149

Zafar MW, Shahbaz M, Hou F, Sinha A (2019) From nonrenewable to renewable energy and its impact on economic growth: the role of research and development expenditures in Asia-Pacific economic Ccoperation countries. J Clean Prod 212:1166-1178. https://doi.org/10.1016/j.jclepro.2018.12.081 